\title{
The Election of a Kleptocrat: Viktor Ianukovych and the Ukrainian Presidential Elections in 2010
}

\author{
Li Bennich-Björkman \\ Uppsala University
}

Andriy Kashyn

Kyiv International Institute of Sociology (KIIS)

Sergiy Kurbatov

Institute of Higher Education, National Academy of Educational Sciences of Ukraine

\begin{abstract}
In 2010, Viktor Ianukovych, a candidate whose democratic credentials were disputed and whose shady background hardly inspired feelings of admiration or trust, was elected president of Ukraine. By asking the voters themselves on the eve of the election how such an individual could have won their votes, this article shows that when Ukrainians went to vote in 2010 , they evaluated the qualities and the policy-issues associated with Ianukovych higher than those ascribed to his opponent, Iuliia Tymoshenko, even if only slightly so. In a Ukraine that since the Orange Revolution in 2004 has come increasingly to embrace democracy, the 2010 presidential elections marked a certain democracy fatigue that in the end came to favour Ianukovych's "strong hand" image. Regional belonging is a usual factor in Ukrainian voting, and it played a role in the political assessments of the 2010 presidential election. However, issues of identity and language were among the lowest ranked in both eastern and western Ukraine, far behind the heated topics of jobs, unemployment, and welfare services. Later, identity-politics became more accentuated in the aftermath of the Revolution of Dignity in 2014 and the ensuing war between Ukraine and Russia. In 2010, what united many voters regardless of region was a stronger concern for jobs and welfare services than for democratic commitment in the candidates, or for identity politics. Those more personal issues paved the way for Ianukovych to become the president of Ukraine.
\end{abstract}

Keywords: Ukraine, elections, Viktor Ianukovych, regional divisions.

\section{INTRODUCTION}

fter being elected in 2010, President Viktor Ianukovych was infamous
for being the pro-Kuchma candidate that just six years earlier was
defeated by the popular uprising of the Orange Revolution (2004-05) (cf.
Simon; Onuch). Four years of his disastrous presidency paved the way for a
formative turn in Ukrainian geopolitical orientation: elections in 2014
represented the strengthening of Ukraine's pro-EU forces. Ianukovych's
presidency increased authoritarian rule in the country, and he, his family 
and close allies enriched themselves in ways that resemble some of the more infamous Eurasian kleptocrats. According to Ukrainian expert Taras Kuzio, Ianukovych created a mafia state in Ukraine ("Ukrainian Kleptocrats"). In February 2014, Ianukovych fled Kyiv for Russia in the midst of widespread protests that shook Ukraine; such protests, originally called Euromaidan, are also known as the Revolution of Dignity (Szostek). Euromaidan began in November 2013 when students objected to the last-minute withdrawal of the president's arrangement to sign the European Union Association Agreement, and quickly grew to challenge the entire Ukraine political system, citing mismanagement, cronyism, and corruption.

What compelled the citizens of Ukraine to elect Viktor Ianukovych? Was it "identity-politics" that sharpened already existing divisions, as Colton has claimed? Did Ukrainian voters choose "the best among the worst" in a situation where the economic situation was alarming, favouring interests over identity, as Bloom and Schulman advocate? Or, as Ryabov suggests, was a vote for Ianukovych a way to reject the alleged "dictatorial" tendencies of the rival Tymoshenko, thus carrying the Orange democratic creed further, although in a distorted manner?

Financial backing from Russia, and Viktor Iushchenko's drive to destroy the chances of Iuliia Tymoshenko by urging his voters to stay away from the polling stations, probably affected the result. However, we show in this article, through analyses of voter surveys, that in 2010, Ukrainian voters evaluated the qualities and the policy issues associated with Ianukovych slightly higher than those ascribed to Tymoshenko. In a Ukraine that since the Orange Revolution in 2004 has increasingly come to embrace democracy, the 2010 presidential elections marked a certain democracy fatigue that in the end came to favour Ianukovych's "strong hand" image (Reznik; Korostelina). The Ianukovych victory over the popular rival Tymoshenko, the "gas princess" of Ukrainian politics, was indeed narrow, only 3.48 percent, indicating a geographically divided Ukrainian electorate after years of political and economic disappointments. However, the fact that regional voting as usual played a role in Ukrainian political assessments does not mean that Ukrainian voters considered issues of identity or language to be of importance in the 2010 presidential elections. In contrast to what is found in a sociological study cited in Fedorenko, Rybiy, and Umland, in which voters in parliamentarian elections are said to prioritize geopolitical over economic concerns, we find that in both eastern and western Ukraine, such issues were among the lowest ranked, far behind the heated topics of jobs, unemployment, and welfare services. If anything, identity politics have become more accentuated in the aftermath of Euromaidan and the war between Ukraine and Russia. What did unite many of the voters regardless of region was a stronger concern for jobs and welfare services than for the 
democratic commitment of the candidates, or identity politics. That paved the way for Ianukovych to become the president of Ukraine.

In this article, the election of Ianukovych as Ukrainian president in 2010 is analyzed through the views of the Ukrainian voters at the time of these elections. Which qualities and which issues did they consider to be the most important in their new president? In the country-wide and representative pre-election surveys regularly carried out by the Kyiv International Institute of Sociology (KIIS), ${ }^{1}$ we hear concerns of Ukrainian voters in 2010 regarding the most important issues and the qualities of the political candidates. The KIIS surveys shed light on three questions: (1) What political issues were of concern to the Ukrainian voters as they elected a new president in January and February of 2010? (2) What kind of political leader were the voters looking for? (3) To what extent did regional belonging suggest a political division between eastern and western Ukraine in these elections?

As the choice of the people has come to matter more, elections and electoral behaviour of Ukrainian voters have attracted growing interest among Ukrainian researchers and social scientists based in the West, in particular since the Orange Revolution in 2004. In Vyshniak's monograph, a Western, more positivist, approach to research on electoral behaviour is combined with Ukrainian social and cultural specifics. Bilousov investigates the objective background and specific subjective features of voters' choices during political and social transformations, whereas the peculiarities of the electoral culture of Ukrainian voters during such transformations are the core of Idrisov's study. Furthermore, regional patterns and voter behaviour are the main subject in Huhnin and Mykhailych's works, as well as in the work of western-based Kubicek and Birch. East European Politics and Societies (see Colton) devoted its first issue in 2011 to the Ukrainian presidential elections where electoral dynamics were explored in several articles based on exit-polls (some are referred to above). D'Anieri ("The Last Hurrah") and Wilson analyzed the role of political technologies in presidential elections of 2004. Kushakova studied the electoral campaign in 2010, stressing the manipulative political technologies of its leaders, Ianukovych, Tymoshenko, Serhii Tihipko, and Arsenii Iatseniuk. She mentions the growing importance of political technologies in Ukrainian political life and identifies such technologies as effective tools for gaining power.

To Western observers, Ianukovych's victory in 2010 has appeared strange, given that he was ridiculed as a convicted criminal only a few years earlier, and it was insinuated in the media that he had limited intellectual

\footnotetext{
1 One of the authors of this article belongs to the KIIS group that was mainly responsible for the surveys and their analyses.
} 
capacities. If anything, his victory, and the developments that followed his ousting, fuelled Western prejudices of non-rational and easily led-on East European voters, who succumb to populist messages and emotional appeals, and of messy politics that appear endogenous in the post-Soviet space. Such factors have been claimed to influence political behaviour in Ukraine, and specifically in the 2004 and 2010 elections (Colton 4-27). In subsequent developments in Ukraine (2014-15), profound differences in geopolitical belonging within the country were demonstrated. Therefore, the "regional" factor in the 2004 and 2010 elections is worth returning to. In this article, we investigate the impact of regional belonging in relation to generational, socio-economic, and gender factors, focusing on (i) how the electorate ranked the priority of policy issues, and (ii) which qualities were preferred in a political leader.

\section{METHODOLOGY}

Public opinion polls have been carried out in Ukraine since the 1990s. The renowned KIIS executed the omnibus pre-election survey "Public Opinion in Ukraine: January 2010," which contained our own questions, among others. ${ }^{2}$ As our commissioned part was an integral element, we describe in some detail the steps by which this survey was carried out. The fieldwork took place January 2-14, 2010 (on the eve of the first round of the presidential elections). Face-to-face interviews took place in the homes of respondents, and the sample developed was representative of Ukraine as a whole and of the four largest regions (west, centre, south, and east) of Ukraine. The sample had a four-stage design, random at each stage. The target Ukrainian population was defined as the resident adult population of individuals aged 18 and older. Persons living in institutions were not included. The sample of households from which persons were selected was based on randomly sampled postal districts within proportionally sampled settlements (e.g., city, town, village).

A stratified, multi-stage area probability sample was employed. Ukraine was then divided into 24 oblasts and the Crimea (Crimea was forcefully annexed to Russia in April 2014). Each oblast was divided into "raions" (or counties), and one city in each oblast was designated as the oblast centre. Each oblast contained cities, towns, villages of the city type (SMT, "selyshche mis'koho typu" in Ukrainian), and villages, reflecting the type of municipal administration granted to the settlement. In the first stage, primary sampling

\footnotetext{
2 This was made possible due to the courtesy of the KIIS management team that supported the academic interests of its employees.
} 
units (PSUs) were selected with a probability proportional to size (PPS) from the cities, towns, and SMTs for urban populations and from raions for rural populations. The sample was drawn such that the urban and rural populations of each oblast were represented proportionally.

Once the PSUs were selected, a sample of postal districts was chosen randomly from the list of residential postal districts within each PSU, taking into account the number of residential districts, which is proportional to the number of apartments. In the third stage, a randomized-number rule was used to select the street, household, and apartment that the interviewer was to visit first.

In the last stage, before selecting the potential respondents, the interviewer enumerated and listed adult (i.e., 18 or older) household members living in a consecutive run of apartments (i.e., from lower to higher apartment numbers) until he or she had a list of occupants sorted by (1) apartment, (2) gender, and (3) age. After generating a list of occupants, the interviewer attempted to recruit every third occupant (i.e., only every third person in a list was a potential respondent) for the study.

The survey was carried out in 109 settlements (PSUs), in all regions of Ukraine and in the autonomous Republic of Crimea. In total, 2040 interviews were conducted. To estimate the sample shifts, the results of the survey were compared to corresponding statistics of the last Ukrainian census conducted in 2001. Overall the accordance of the sample and statistics appeared to be satisfactory. Particularly, the comparison of the survey data to statistics distributions by settlement type and by four regions revealed the accuracy of sample realization by interviewers; the regional and settlement type distributions were pre-set in the sample structure. A variable of weight was constructed to adjust the data shifts.

The theoretical sample error without design effect constituted 2.2 percent (in a sample size of 2040); a design effect for the majority of variables was not more than 1.5. In this survey 10 percent of the interviews were controlled. That included a controlled analysis of the interviewers' diaries and a control of the fact and the quality of the interview ${ }^{3}$ in a certain household. 4

\footnotetext{
${ }^{3}$ Separate quality control teams repetitively visited randomly selected households from the sample and checked whether interviews were conducted with respondents, checked respondents' demographic information, asked about the tentative length of the interview and topics covered during it.

4 During fieldwork, the interviewers made three attempts to reach a potential respondent. If this was unsuccessful, they turned to additional addresses. The characteristics of non-respondents were usually not analyzed because reasons for non-response were the absence of everyone in a household at the time of the visit, or refusal to communicate with an interviewer. Thus, there was no knowledge about the
} 
Analyses of the diaries were intended to control the correctness of the respondent selection procedure (usage of correct base numbers and the selection of potential respondents), and the correctness of the final selection within each household (the reasons for refusals to answer individual questionnaires were described). The specially developed questionnaire of controllers $^{5}$ served to control the fact and the quality of realization of concrete interviews. We believe that the reliability and validity of the results were secured through the measurements and precautions described above.

\section{SETTING THE StAgE For 2010 ELECTIONS: ThE UKRAINIAN CONTEXT}

Following independence in 1991, Ukraine was for a decade (1994-2004) characterized by an increasingly authoritarian and corrupt rule under President Leonid Kuchma, followed by a strengthening of democratic tendencies in terms of fair elections and increasing media freedom as a result of the Orange Revolution (D'Anieri, Understanding Ukrainian Politics, Ch. 4; Hale). However, although parliamentary elections after 2004 were assessed by international observers as free and fair-deteriorating in 2012 (Kovalov) but again improving in presidential and parliamentary elections in 2014-political turbulence nevertheless became a destructive sign of Ukrainian political life (O’Brien; Kuzio, "Rise and Fall”). The former "Orange" allies, Iushchenko and Tymoshenko, became political enemies, while the third important personality in Ukrainian politics at the time, Ianukovych, managed to keep his position as a forefront figure of the Party of Regions, at times joining forces with the Tymoshenko bloc (BIUT) for strategic reasons. After parliamentary elections in 2008, for several months it was impossible to form a government, and the infighting and personal struggles obstructed decision making, putting a halt to urgently needed economic reforms. This contributed to the severe ramifications in the Ukrainian economy of the global economic crises in 2008-09.

Not only has Ukrainian politics been unusually turbulent and marked by recurring dead-locks (the economy is one of the worst in the post-Soviet space), there are also wide-spread and continuous accusations of systemic corruption, of intimate ties between business and politics (Puglisi), and of parliamentary seats and places on party lists being for sale to the highest bidder (Slomczynski et al.). The problematic role of the oligarchs-superrich

non-respondents. To account for potential biases, we compared sample demography statistics with one of the censuses and calculated a weight variable if it was needed.

${ }^{5}$ Controllers are teams of specially trained employees in each oblast of Ukraine who report to a quality control manager and work independently of fieldwork department. 
businessmen - in Ukrainian society and political life continues to be an issue after the Ianukovych era. Kuzio considers the possibility of programmatic parties (i.e., the ones mainly driven by ideas and ideology) to be far-fetched in Ukraine, due to a political culture of deep-rooted patronage and personalistic politics. The Party of Regions, the Ianukovych party, is considered by Kuzio to be a machine-type party, that is, a party that relies on individual favours in return for votes, not an idea-based party that relies on ideological messages or visions of reform ("Rise and Fall").

The Corruption Perception Index (CPI), published yearly by Transparency International (TI), ranked Ukraine 152 of 182 (where 1 is the least corrupt) countries in 2011. Together with Russia, which shared a similar position, Ukraine performed worst among post-Soviet countries located in Europe. The problem of corruption in state establishments challenges Ukrainian state-building and prosperity the most. In 2009,6 before the 2010 elections, an overwhelming number (94 percent) of Ukrainians considered corruption to be an important problem. Many Ukrainians have reported experiencing corruption-63 percent in 2009 stated that they encountered various forms of corruption in state establishments. According to public opinion, the most corrupt state sectors were the state car-inspection (road police), the judicial system, the militia, the state medical establishments, and the prosecutor's office. Whereas Ukrainian politics moved away from the Kuchma-era and the authoritarian tendencies in the period leading up to the 2010 presidential elections, severe political problems and a devastating level of corrupt practices continued to plague the new state.

At the eve of the elections, most Ukrainians shared a negative view of important state institutions such as the Verkhovna Rada (Ukrainian Parliament), and the president and the cabinet of ministers. Trust in these major state institutions can be described as extremely low also from a postCommunist perspective. In November 2009, only 12 percent of Ukrainians stated that they had great confidence in the Verkhovna Rada, and just slightly more-13 percent-reported confidence in the Ukrainian president. One fifth (19 percent) had confidence in the Cabinet of Ministers of Ukraine. However, trust in political authorities increased at the local level. ${ }^{7}$ For instance, 32 percent trusted their oblast governor and even more (45 percent) trusted their city/village council. This shows that the central authorities primarily lacked legitimacy, and that local identities were strong in Ukraine in the period preceding the 2010 elections (see Diagram 1).

\footnotetext{
${ }^{6}$ Corruption in Ukraine Survey for MCC Threshold Country Program in Ukraine was conducted by KIIS February-March 2009 (N=10577).

7 Survey of IFES, November 2009. The sample consisted of 1502 respondents.
} 


\title{
Diagram 1
}

\author{
How much confidence do you have in ... $(n=1502)$ \\ President Viktor Iushchenko \\ The Verkhovna Rada \\ Ministry of Justice \\ The Cabinet of Ministers \\ Your Oblast governor \\ Your Raion administrator \\ Prime Minister Iuliia Tymoshenko \\ Your City/Village council \\ Mayor of your city/village local...

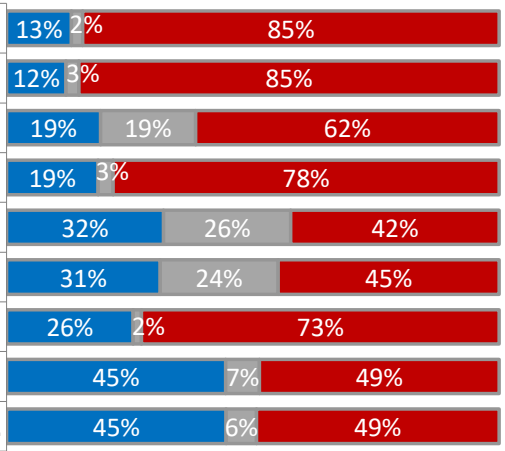 \\ n Great deal/Fair amount $\square$ DK/NR $\square$ Not very much/Not at all
}

In neighbouring Russia the support for equivalent state institutions was much higher than in Ukraine; thus, Ukraine's very low support figures cannot be regarded as a regionally established trend. Around 70 percent of Russians felt confidence in the Russian president, approximately 50 percent trusted the Russian government, and 30 percent trusted the Russian parliament ("Reitingi"). There is thus nothing self-evident, given the country's Soviet background, in the skepticism demonstrated by Ukrainians. Reasons for the wide-spread institutional distrust can be found in the negative perceptions of Ukrainian politicians who stand as representatives of what is believed to be highly corrupt institutions of state and government. A survey ${ }^{8}$ made during the presidential electoral campaign in 2009 showed that a majority of Ukrainians were skeptical of both the candidates and their pre-election promises. Three percent (!) of respondents believed that politicians were honest in stating their incomes, and only a mere 7 percent of respondents believed that the candidates would conduct their campaigns in a clean manner (see Diagram 2).

8 The survey was made by KIIS December 2009; an all Ukrainian sample included 400 respondents. 


\section{Diagram 2}

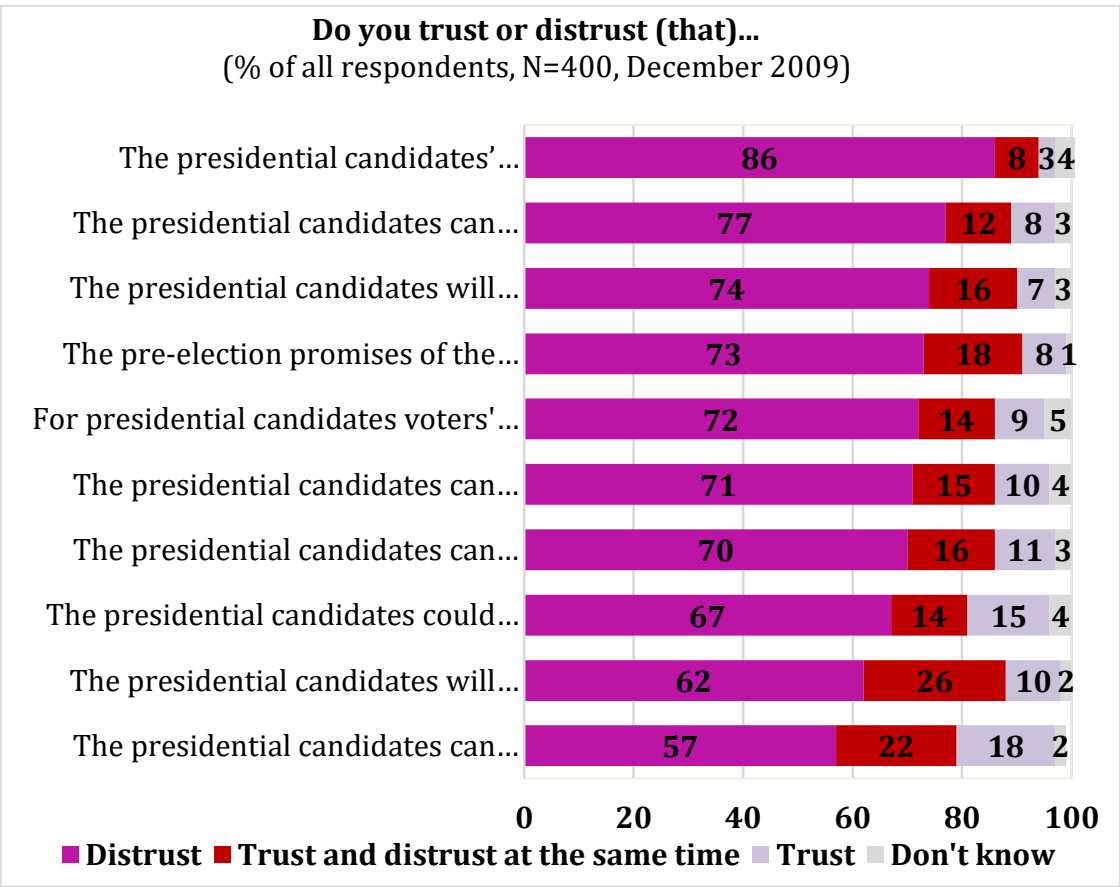

Tensions furthermore existed between subgroups of the Ukrainian population and the elites that represented them. Controversial issues included the relationship with the EU and NATO, the relationship with Russia, the status of the Russian language, and how to understand and commemorate both the western Ukrainian partisan movement (OUN-UPA) during World War II and the disastrous Ukrainian famine of 1932-33-the Holodomor (for an empathic and emotionally strong description of the famine see Snyder). Sentiments and assessments of the Soviet past, of identity and collective memories, indicate that Ukraine is, as has often been stated, a divided country in certain respects. Public opinion in the country is strongly polarized with respect to the above-mentioned problems and politicians often feed on this polarization during election campaigns (Osipian and Osipian). Such polarization is especially significant for Ukrainians who are living in regions with various historical and cultural backgrounds, although their importance in political behaviour is being disputed (Kubicek). The most vivid case can be seen by comparing the views of eastern and western Ukrainians. 
In Ukraine today, two of the most contested phenomena of the twentieth century are the creations of the Ukrainian Insurgent Army (UPA) and the Organization of Ukrainian Nationalists (OUN), both with geographical and ideological bases in Galicia (part of western Ukraine). OUN split in 1941 into OUN-B and OUN-M (the latter under the leadership of Andrii Mel'nyk). Stepan Bandera, the leader of OUN-B, is the more well-known of the two leaders and his leadership remains highly contested in the collective memories of Ukrainians and in Ukrainian history. For many in western Ukraine, Bandera is a hero, although with bloodied hands, who fought for Ukrainian independence against the Soviets; for many in eastern Ukraine, Bandera is a war criminal and a brutal killer (Yurchuk). The Stalin-induced famine in Ukraine of 1932-33-the Holodomor-is yet another part of Ukrainian history that is sensitive and partly contested (Applebaum).

Inhabitants of western Ukraine (a part of Ukraine that belonged to Poland, Romania, and Czechoslovakia before World War II) strongly support joining the European Union (EU) and the North Atlantic Treaty Organization (NATO), and oppose close relations with Russia or the recognition of Russian as an official language. Eastern Ukrainians, however, fight for close ties with Russia; they welcome the Russian language as the second state language of Ukraine and display some antagonism toward NATO. Events during and after the Euromaidan protests have demonstrated the salience of these divisions. Although present in the Ukrainian context for a long time, these divisions have not caused severe conflict.

Ukraine was severely hit by the global economic crisis in 2008. Due to economic conditions in Ukraine (such as export structure, inefficient industry), and for political reasons (populism, the perceived irresponsibility of political leaders facing the crisis, a lack of coordination and even direct confrontation between president and prime minister), the 2008 economic crisis had an even greater impact on Ukraine than on many other postCommunist countries. The most vivid examples of political populism were the denial of a financial crisis (at its beginning) by Prime Minister Tymoshenko (see Iashchenko), and the support loans (multi-billions) given by the National Bank of Ukraine to some of the commercial banks without any transparency in the procedure of choosing loan recipients.

The consequences to Ukraine of the 2008 global financial crisis was a decline in GDP (in 2009 it declined by 15.1 percent, and the GDP per capita was approximately $\$ 2834.34$ in 2009; see "Ukraine GDP"), a radical devaluation of the national currency, a growth in unemployment, and a general decline in salaries (by 9.2 percent in 2009) and incomes (by 8.5 percent in 2009). The average Ukrainian salary was $\$ 238$ per month in 2009 (the minimal salary was approximately $\$ 100$ per month), and it was strongly influenced by the volatility in the national currency and the high inflation. 
Severe economic problems, detailed below, were also prominent considerations for Ukrainian voters in the 2010 presidential elections.

\section{THE Most IMPORTANT ISSUES}

As Diagram 3 shows, in the pre-election survey of 2010, two thirds of the respondents shared the opinion that creating jobs and reducing unemployment was the issue that should be prioritized. As Wilson and Birch noted, voters in many of the post-Communist states, including Ukraine, consistently regarded unemployment as a major policy concern. In the 2010 elections, 44 percent thought that attention should be paid first to pensions and wages. Reducing corruption was thought to be a prominent issue by more than a third of respondents, 36 percent. Almost the same quantity -34 percent-expressed the opinion that keeping inflation down and prices low were the highest priorities. Other issues were supported by significantly fewer respondents. Questions touching upon Ukraine's relations to other states and international politics-for example, the status of the Russian language and the relations between Ukraine and the Western organizations - the EU and NATO-constituted marginal questions in the eyes of voters. Though questions such as these often had been the focus of international media coverage of Ukraine even before Euromaidan 2014, they had little leverage in the minds of the average Ukrainian voter in 2010. In an April 2014 survey by KIIS, although a tense situation plagued southern and eastern Ukraine at that time, issues of language were not considered to be pivotal ("Dumky ta pohliady"). The societal concerns of Ukrainian citizens were characteristically down-to-earth, that is, material well-being (wellpaid jobs) was believed to be the top priority issue for Ukrainian leaders to deal with. As in the Western world, issues of welfare and employment are highlighted in Ukraine during elections, whereas foreign policy issues usually have little impact on electoral choice (Dalton 207). 


\section{Diagram 3}

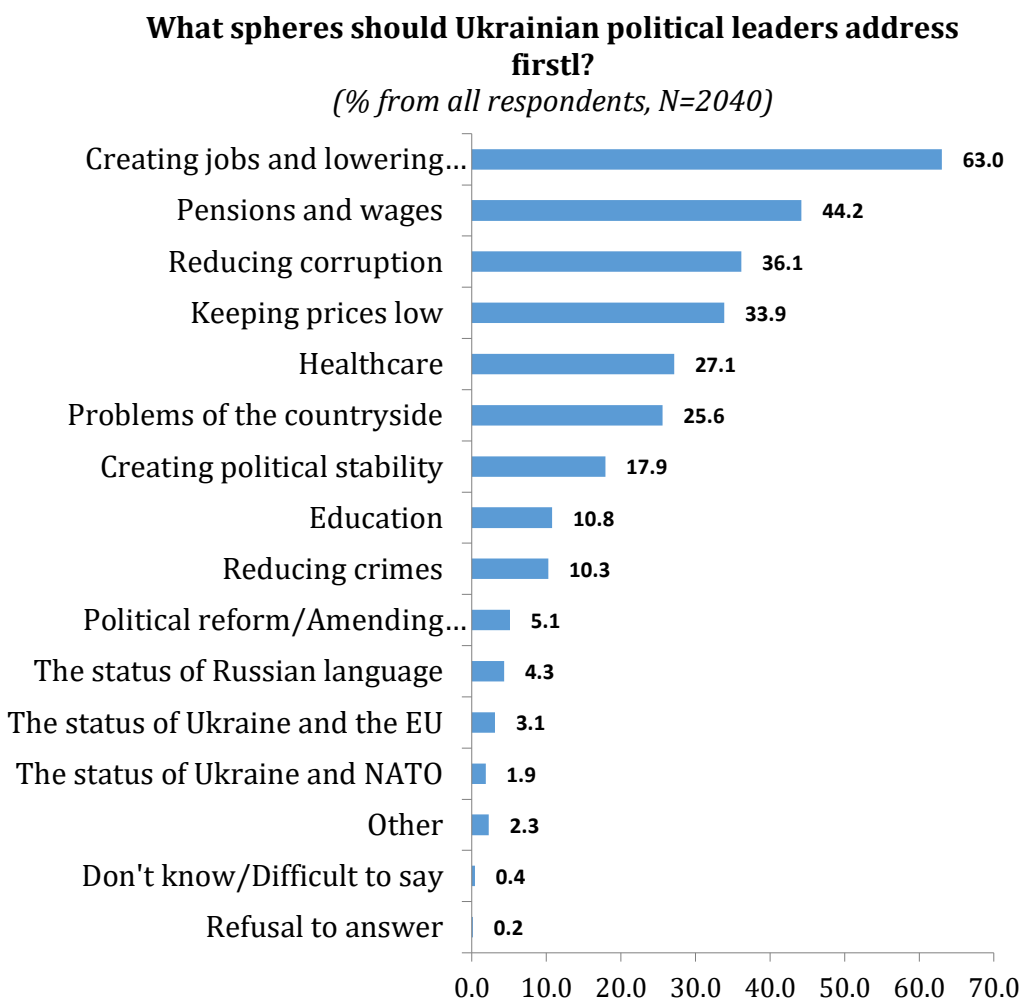

In addition to age, gender, and educational level, regional belonging was important to the way issues were ranked. This confirms previous results that found that regional divisions were important factors in political behaviour and choice. ${ }^{9}$ Regional patterns showed themselves most prominently in issues that were considered to be most important by eastern and western Ukrainians. As shown in Diagram 3, more than one third $(36.1 \%)$ of Ukrainians considered corruption to be wide-spread and problematic. However, the number of respondents who considered the reduction of corruption to be a top priority decreased from the west to the east of Ukraine, from 42 percent in the west to 26 percent in the east (Table 1). This suggests that there was a higher acceptance of corrupt practices in the east and points to deep-lying differences in political culture (cf. Denisova-

9 Kubicek cites that regional belonging was influential in the first presidential elections of 1991 and 1994 (283). 
Schmidt and Huber). In eastern and southern Ukraine more people considered the status of the Russian language and pensions and wages to be top priorities, putting less value on the reduction of crime. However, both in western and eastern Ukraine there was similar emphasis among voters on the importance of lowering unemployment and creating jobs. When it came to "survival" issues for individual households, there were no significant differences.

Table 1. What issues should the Ukrainian political leaders address first? (percent by region)

\begin{tabular}{|c|c|c|c|c|}
\hline & Region & & & \\
\hline & Western & Central & Southern & Eastern \\
\hline Reducing corruption & 42.4 & 37.2 & 37.8 & 26.2 \\
\hline $\begin{array}{l}\text { Creating jobs and lowering } \\
\text { unemployment }\end{array}$ & 67.5 & 59.5 & 59.1 & 67.8 \\
\hline Keeping prices low & 35.2 & 29.1 & 31.8 & 41.4 \\
\hline Creating political stability & 19.6 & 14.8 & 18.9 & 19.0 \\
\hline The status of Russian language & 1.0 & 1.1 & 7.5 & 8.2 \\
\hline Reducing crimes & 12.0 & 13.0 & 7.9 & 7.6 \\
\hline Healthcare & 20.5 & 27.9 & 30.1 & 29.4 \\
\hline Education & 7.4 & 12.2 & 11.4 & 11.7 \\
\hline
\end{tabular}


Table 1 continues.

\begin{tabular}{|c|c|c|c|c|}
\hline & \multicolumn{4}{|l|}{ Region } \\
\hline & Western & Central & Southern & Eastern \\
\hline $\begin{array}{l}\text { Political reform/Amending } \\
\text { Constitution }\end{array}$ & 6.9 & 5.2 & 5.6 & 2.7 \\
\hline The status of Ukraine and the EU & 3.5 & 3.2 & 3.7 & 2.0 \\
\hline The status of Ukraine and NATO & 3.2 & 2.2 & 1.5 & 0.4 \\
\hline Problems of the countryside & 23.1 & 33.4 & 21.5 & 22.7 \\
\hline Pensions and wages & 38.4 & 39.5 & 46.9 & 53.3 \\
\hline Other & 1.7 & 3.2 & 3.4 & 0.5 \\
\hline Don't know/Difficult to say & 1.2 & 0.3 & 0.2 & 0.2 \\
\hline Refusal to answer & 0.4 & 0.2 & 0.0 & 0.0 \\
\hline
\end{tabular}

Ianukovych's adherents were not highly concerned about corruption. Only twenty seven percent stated that the issue of corruption was a top priority for Ukrainian leaders (Table 2). Job creation was an issue singled out by the adherents of Tihipko, one of the other contenders, and of Ianukovych, and the electorate of Ianukovych also put an emphasis on securing and increasing pensions and wages. Among those intending to vote for Tymoshenko and Iatseniuk, third and fourth contenders to the presidency, almost no respondents considered the status of the Russian language as a top priority (as opposed to 8 and 7 percent of the individuals who voted for Tihipko and Ianukovych).

Respondents who were ready to support Ianukovych in the second round of the presidential elections referred to low employment, the status of the Russian language, and pensions and wages more often than Tymoshenko's electorate. In the second round, Tymoshenko's electorate believed that attention should be drawn first to reducing corruption, reducing crime, and to environmental problems. 
Table 2. What issues should the Ukrainian political leaders address first? (percent by political choice)

\begin{tabular}{|c|c|c|c|c|c|c|c|}
\hline & \multicolumn{4}{|c|}{$\begin{array}{l}\text { Presidential election, } \\
1 \text { tour }\end{array}$} & \multicolumn{3}{|c|}{$\begin{array}{l}\text { Presidential election, } \\
2 \text { tour }\end{array}$} \\
\hline & 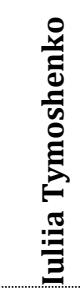 & 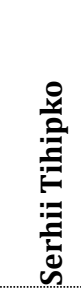 & 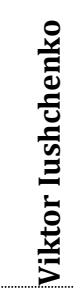 & 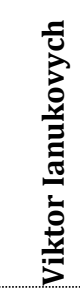 & 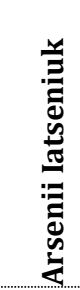 & 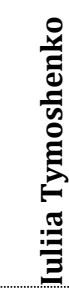 & 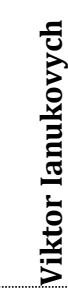 \\
\hline Reducing corruption & 39.2 & 43.4 & 49.0 & 26.9 & 47.9 & 40.7 & 29.5 \\
\hline $\begin{array}{l}\text { Creating jobs and } \\
\text { lowering } \\
\text { unemployment }\end{array}$ & 60.8 & 67.1 & 58.2 & 68.8 & 53.7 & 60.8 & 67.3 \\
\hline Keeping prices low & 34.9 & 27.7 & 25.9 & 37.2 & 36.1 & 33.7 & 35.2 \\
\hline $\begin{array}{l}\text { Creating political } \\
\text { stability }\end{array}$ & 20.3 & 27.5 & 23.3 & 16.1 & 20.8 & 19.6 & 17.1 \\
\hline $\begin{array}{l}\text { The status of the } \\
\text { Russian language }\end{array}$ & 1.1 & 8.2 & 0.0 & 7.3 & 0.7 & 0.9 & 7.8 \\
\hline Reducing crimes & 12.9 & 11.2 & 10.6 & 7.2 & 14.9 & 11.6 & 7.3 \\
\hline Healthcare & 29.2 & 23.8 & 17.4 & 29.3 & 22.3 & 27.3 & 29.0 \\
\hline Education & 12.3 & 10.1 & 7.6 & 9.4 & 10.1 & 11.6 & 9.2 \\
\hline $\begin{array}{l}\text { Political } \\
\text { reform/Amending } \\
\text { Constitution }\end{array}$ & 4.9 & 7.7 & 6.6 & 3.8 & 10.1 & 5.6 & 4.5 \\
\hline $\begin{array}{l}\text { The status of Ukraine } \\
\text { and the EU }\end{array}$ & 4.3 & 5.4 & 9.2 & 2.2 & 3.7 & 4.1 & 2.5 \\
\hline $\begin{array}{l}\text { The status of Ukraine } \\
\text { and NATO }\end{array}$ & 2.3 & 2.1 & 10.7 & 1.0 & 1.1 & 2.7 & 0.8 \\
\hline
\end{tabular}


Table 2 continues.

\begin{tabular}{|c|c|c|c|c|c|c|c|}
\hline & \multicolumn{4}{|c|}{$\begin{array}{l}\text { Presidential election, } \\
1 \text { tour }\end{array}$} & \multicolumn{3}{|c|}{$\begin{array}{l}\text { Presidential election, } \\
2 \text { tour }\end{array}$} \\
\hline & 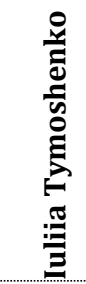 & 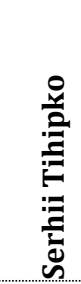 & 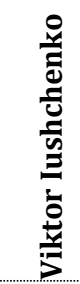 & 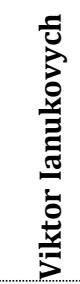 & 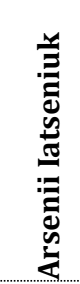 & 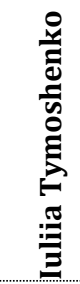 & 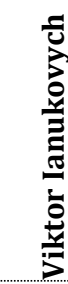 \\
\hline $\begin{array}{l}\text { Problems of the } \\
\text { countryside }\end{array}$ & 25.2 & 21.0 & 30.2 & 23.5 & 28.2 & 27.9 & 22.6 \\
\hline Pensions and wages & 41.7 & 34.0 & 31.0 & 53.5 & 43.0 & 38.8 & 52.0 \\
\hline Other & 1.9 & 2.9 & 2.2 & 2.6 & 0.0 & 2.6 & 2.7 \\
\hline $\begin{array}{l}\text { Don't know/Difficult } \\
\text { to say }\end{array}$ & 0.2 & 0.4 & 0.9 & 0.3 & 0.0 & 0.4 & 0.2 \\
\hline Refusal to answer & 0.0 & 0.0 & 1.4 & 0.0 & 0.0 & 0.0 & 0.0 \\
\hline
\end{tabular}

Differences between generations, between men and women, and between individuals with different educational levels were prevalent. Although 66-69 percent of respondents of non-pension age (under 60) believed it was a priority to reduce unemployment, only 52 percent of senior citizens supported this plan. At the same time, a majority (61 percent) of respondents thought the first priorities should be pensions and wages. Older respondents put less emphasis on problems connected with employment and education and paid more interest to pensions and health care.

Men (43 percent) were more inclined than women (31 percent) to emphasise that reducing corruption should be a top priority (Table 3). Meanwhile, among women, keeping prices low (37 percent women to 31 percent men), the importance of health care (31 percent women to 22 percent men), education (13 percent women to 8 percent men), and pensions and wages (48 percent women to 40 percent men) were considered highly important. The difference in gender-related activities (for example, more men in Ukraine have salaried work, while more women are occupied in the household) can be expected to affect a respondent's perception of which issues are of utmost concern. However, such differences were limited according to this survey. 
Table 3. What spheres should the Ukrainian political leaders address first of all? (percent by sex and age groups)

\begin{tabular}{|c|c|c|c|c|c|c|}
\hline & & & & & & \\
\hline & Male & Female & 18-29 & $30-44$ & $45-59$ & $60+$ \\
\hline Reducing corruption & 42.7 & 30.8 & 40.0 & 36.8 & 39.9 & 28.9 \\
\hline $\begin{array}{l}\text { Creating jobs and } \\
\text { lowering } \\
\text { unemployment }\end{array}$ & 63.4 & 62.7 & 67.1 & 68.9 & 65.5 & 51.9 \\
\hline Keeping prices low & 30.5 & 36.6 & 36.5 & 28.6 & 31.3 & 39.1 \\
\hline $\begin{array}{l}\text { Creating political } \\
\text { stability }\end{array}$ & 19.7 & 16.4 & 18.8 & 21.6 & 17.9 & 13.6 \\
\hline $\begin{array}{l}\text { The status of the } \\
\text { Russian language }\end{array}$ & 4.9 & 3.9 & 4.4 & 4.4 & 4.0 & 4.5 \\
\hline Reducing crime & 10.3 & 10.2 & 13.9 & 9.0 & 10.3 & 8.5 \\
\hline Healthcare & 22.0 & 31.3 & 19.2 & 26.9 & 26.8 & 34.1 \\
\hline Education & 8.3 & 12.8 & 15.7 & 15.3 & 7.9 & 5.1 \\
\hline $\begin{array}{l}\text { Political } \\
\text { reform/Amending } \\
\text { Constitution }\end{array}$ & 6.3 & 4.1 & 6.2 & 4.8 & 5.1 & 4.5 \\
\hline $\begin{array}{l}\text { The status of Ukraine } \\
\text { and the EU }\end{array}$ & 3.7 & 2.7 & 4.8 & 2.7 & 3.7 & 1.7 \\
\hline $\begin{array}{l}\text { The status of Ukraine } \\
\text { and NATO }\end{array}$ & 2.3 & 1.5 & 2.7 & 1.8 & 1.4 & 1.7 \\
\hline $\begin{array}{l}\text { Problems of the } \\
\text { countryside }\end{array}$ & 26.6 & 24.8 & 20.6 & 25.9 & 29.7 & 25.7 \\
\hline Pensions and wages & 39.9 & 47.8 & 34.0 & 39.3 & 40.1 & 61.0 \\
\hline Other & 3.1 & 1.7 & 2.1 & 1.8 & 2.3 & 2.9 \\
\hline $\begin{array}{l}\text { Don't know/Difficult } \\
\text { to say }\end{array}$ & 0.6 & 0.3 & 0.7 & 0.4 & 0.1 & 0.7 \\
\hline Refusal to answer & 0.1 & 0.2 & 0.3 & 0.2 & 0.0 & 0.2 \\
\hline
\end{tabular}


Differences between subgroups of respondents with various levels of education are shown in Table 4 . Survival issues related to the economy were prioritized by respondents with lower education. Among these were keeping prices low (from 46 percent in a subgroup with incomplete secondary education to 24 percent in a subgroup with higher education) and giving priority to pensions and wages (from 64 percent in a subgroup with incomplete secondary education and 33 percent in a subgroup with higher education). For people with incomplete secondary education, problems of the countryside (35 percent) and healthcare (35 percent) were more important than for respondents with higher education (22 percent and 24 percent, respectively). At the same time, respondents with a higher level of education expected leaders to deal with political issues such as reducing corruption (21 percent in a subgroup with incomplete secondary education and 45 percent in a subgroup with higher education) and creating political stability ( 9 percent in a subgroup with incomplete secondary education and 24 percent in a subgroup with higher education). Issues of education were emphasized more by respondents from the higher education subgroup (13 percent) compared with respondents in the incomplete secondary education subgroup (5 percent), A similar respondent education pattern was displayed with respect to support for political reforms/amending the Constitution (8 percent and 2 percent, respectively) and concern for the status of Ukraine and the EU ( 6 percent and 1 percent, respectively).

Table 4. What issues should the Ukrainian political leaders address first? (percent by level of education)

\begin{tabular}{|l|l|l|l|l|}
\hline & $\begin{array}{l}\text { Level of education } \\
\text { Incomplete } \\
\text { secondary }\end{array}$ & Secondary & $\begin{array}{l}\text { Secondary } \\
\text { specialized }\end{array}$ & Higher \\
Reducing corruption & 20.5 & 32.7 & 40.0 & 44.7 \\
$\begin{array}{l}\text { Creating jobs and } \\
\text { lowering } \\
\text { unemployment }\end{array}$ & 55.7 & 63.3 & 65.4 & 24.3 \\
\hline $\begin{array}{l}\text { Keeping prices low } \\
\text { Creating political } \\
\text { stability }\end{array}$ & 45.8 & 38.4 & 19.8 & 23.8 \\
\hline $\begin{array}{l}\text { The status of the } \\
\text { Russian language }\end{array}$ & 4.2 & 15.8 & 3.8 \\
\hline
\end{tabular}


Table 4 continues.

\begin{tabular}{|c|c|c|c|c|}
\hline & \multicolumn{4}{|c|}{ Level of education } \\
\hline & $\begin{array}{l}\text { Incomplete } \\
\text { secondary }\end{array}$ & Secondary & $\begin{array}{l}\text { Secondary } \\
\text { specialized }\end{array}$ & Higher \\
\hline Reducing crime & 9.9 & 11.1 & 9.2 & 10.5 \\
\hline Healthcare & 34.8 & 25.6 & 29.0 & 23.8 \\
\hline Education & 4.8 & 9.7 & 12.9 & 13.1 \\
\hline $\begin{array}{l}\text { Political } \\
\text { reform/Amending } \\
\text { Constitution }\end{array}$ & 2.2 & 3.6 & 6.3 & 7.5 \\
\hline $\begin{array}{l}\text { The status of Ukraine } \\
\text { and the EU }\end{array}$ & 0.8 & 2.1 & 2.8 & 6.0 \\
\hline $\begin{array}{l}\text { The status of Ukraine } \\
\text { and NATO }\end{array}$ & 0.3 & 1.8 & 1.7 & 2.8 \\
\hline $\begin{array}{l}\text { Problems of the } \\
\text { countryside }\end{array}$ & 34.5 & 26.7 & 23.8 & 21.5 \\
\hline Pensions and wages & 63.9 & 46.6 & 42.6 & 33.3 \\
\hline Other & 0.3 & 1.6 & 1.6 & 4.9 \\
\hline $\begin{array}{l}\text { Don't know/Difficult } \\
\text { to say }\end{array}$ & 0.7 & 0.4 & 0.3 & 0.6 \\
\hline Refusal to answer & 0.5 & 0.1 & 0.0 & 0.2 \\
\hline
\end{tabular}

\section{QUALITIES LOOKED FOR}

What qualities did the Ukrainian voters look for in their future president? The pre-election survey shows that the main desired quality was honestythis was expressed by as many as 50 percent of respondents (Diagram 4). Given the bleak picture of Ukrainian politics, marred by corruption and inbreeding, this wish for honesty was not surprising. One third (36 percent) of respondents preferred an effective politician to possess strong leadership qualities; in the post-Soviet context this could indicate a desire for strongman rule with a leader who takes on a large share of power (and thus 
responsibility). Intelligence (wisdom) was mentioned by 31 percent, almost the same number of respondents who considered trustworthiness to be important (in the sense that programs declared in the electoral campaign would be a focus of the regime). Other desired qualities were good managerial skills (28 percent), respect for law and justice (27 percent), and experience (24 percent).

\section{Diagram 4}

What qualities should an effective Ukrainian political leader have?

( $\%$ from all respondents, $n=2040$ )

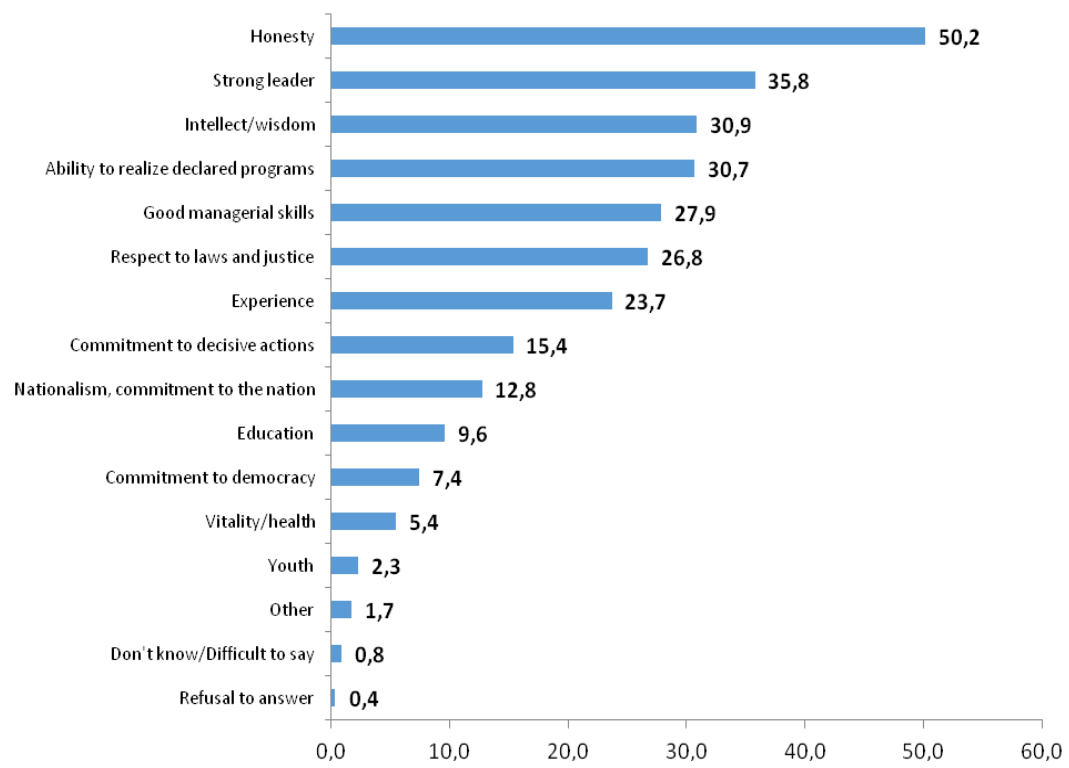

Despite the nation-building attempts by pro-Ukrainian parties (such as Our Ukraine Bloc, People's Movement of Ukraine [RUKH], and Bloc of Iuliia Tymoshenko [BIUT]), commitment to the nation was not a quality prioritized by voters in the Ukrainian president to be (12.8 percent). Commitment to democracy was considered by voters to be even less important (only 7.4 percent).

Factors of age, education, and gender did not have much explanatory value where the issue of leadership qualities was concerned. Representatives of different generations and educational levels, as well as men and women, harboured similar outlooks. Moreover, representatives of the two biggest national groups in Ukraine, namely Ukrainians and Russians, shared similar views. There were some not very substantial differences 
determined by regional belonging (see Table 5). Thus, the percentage of voters who considered intelligence/wisdom important decreased from 39 percent in the west to 25 percent in the east. ${ }^{10}$ Commitment to the nation was more important for almost a quarter of western Ukrainians (24 percent), compared to 8-11 percent in the other regions. In the east, more emphasis was put on experience (38 percent compared to 20-24 percent in other regions).

Table 5. What traits should an effective Ukrainian political leader have? (\% by macroregion)

\begin{tabular}{|c|c|c|c|c|c|}
\hline \multirow{2}{*}{ Trait } & \multirow{2}{*}{ Ukraine } & \multicolumn{4}{|c|}{ Macroregion } \\
\hline & & Western & Central & Southern & Eastern \\
\hline Intellect/wisdom & 30.9 & 39.4 & 33.9 & 25.0 & 25.4 \\
\hline $\begin{array}{l}\text { Nationalism, } \\
\text { commitment to the } \\
\text { nation }\end{array}$ & 12.8 & 24.3 & 8.8 & 8.9 & 10.9 \\
\hline $\begin{array}{l}\text { Commitment to } \\
\text { democracy }\end{array}$ & 7.4 & 9.8 & 8.0 & 4.9 & 7.3 \\
\hline Honesty & 50.2 & 51.9 & 42.1 & 55.1 & 53.2 \\
\hline Strong leader & 35.8 & 31.7 & 41.5 & 31.2 & 38.0 \\
\hline Experience & 23.7 & 19.7 & 16.2 & 23.7 & 38.0 \\
\hline $\begin{array}{l}\text { Ability to realize } \\
\text { declared programs }\end{array}$ & 30.7 & 28.3 & 31.8 & 33.0 & 28.9 \\
\hline Education & 9.6 & 11.4 & 7.3 & 12.8 & 7.1 \\
\hline Vitality/health & 5.4 & 1.5 & 8.8 & 5.6 & 4.9 \\
\hline
\end{tabular}

10 WESTERN REGION: Volyn, Zakarpattia, Ivano-Frankivsk, Lviv, Rivne, Ternopil, Khmelnytskyi and Chernivtsi oblasts. CENTRAL REGION: Kyiv city and Kyiv, Vinnytsia, Zhytomyr, Kirovohrad, Poltava, Sumy, Cherkasy and Chernihiv oblasts. SOUTHERN REGION: the Autonomous Republic of Crimea, Dnipropetrovsk, Zaporizhzhia, Mykolaiv, Odesa and Kherson oblasts. EASTERN REGION: Donetsk, Luhansk and Kharkiv oblasts. 
Table 5 continues.

\begin{tabular}{|c|c|c|c|c|c|}
\hline \multirow{2}{*}{ Trait } & \multirow{2}{*}{ Ukraine } & \multicolumn{4}{|c|}{ Macroregion } \\
\hline & & Western & Central & Southern & Eastern \\
\hline Youth & 2.3 & 1.4 & 3.5 & 2.2 & 1.7 \\
\hline $\begin{array}{l}\text { Good managerial } \\
\text { skills }\end{array}$ & 27.9 & 20.7 & 30.1 & 27.1 & 33.4 \\
\hline $\begin{array}{l}\text { Respect to laws } \\
\text { and justice }\end{array}$ & 26.8 & 22.6 & 25.7 & 31.7 & 26.4 \\
\hline $\begin{array}{l}\text { Commitment to } \\
\text { decisive actions }\end{array}$ & 15.4 & 12.4 & 18.2 & 16.2 & 13.7 \\
\hline Other & 1.7 & 2.1 & 2.4 & 1.2 & 1.0 \\
\hline $\begin{array}{l}\text { Don't } \\
\text { know/Difficult to } \\
\text { say }\end{array}$ & 0.8 & 1.0 & 1.6 & 0.3 & 0.5 \\
\hline Refusal to answer & 0.4 & 0.9 & 0.1 & 0.0 & 0.6 \\
\hline
\end{tabular}

There were no significant differences in the ranking of managerial qualities between representatives of the two biggest national groups (Russian and Ukrainian), but personal qualities in political leaders were viewed differently by people speaking Ukrainian and people speaking Russian (Table 6). ${ }^{11}$ Ukrainian-speaking voters valued intelligence/wisdom (34 percent), nationalism, commitment to the nation (17 percent), and commitment to democracy ( 9 percent) more highly than people speaking Russian (27 percent, 10 percent, and 6 percent, respectively). Traits valued more highly by Russian-language speakers than by Ukrainian-language speakers were honesty (54 to 47 percent), experience (28 to 17 percent), and good managerial skills (30 to 25 percent).

\footnotetext{
${ }^{11}$ In Ukraine, many identify themselves as Ukrainians but use the Russian language in their everyday life (the language used does not always depend on nationality). Usage of Ukrainian or Russian language by respondents depended more on the region where they lived than on their nationality. Therefore, there will be some differences in the ranking of qualities due to the language variable, as well as to the region lived in.
} 
Table 6. What qualities should an effective Ukrainian political leader have? (\% by usage of language)

\begin{tabular}{|c|c|c|}
\hline \multirow{2}{*}{ Trait } & \multicolumn{2}{|c|}{ Speaking language } \\
\hline & Ukrainian & Russian \\
\hline Intellect/wisdom & $34.4-3$ & 27.4 \\
\hline Nationalism, commitment to the nation & 17.3 & 9.6 \\
\hline Commitment to democracy & 8.9 & 6.0 \\
\hline Honesty & 47.0 & 54.0 \\
\hline Strong leader & 37.4 & 34.7 \\
\hline Experience & 17.0 & 28.3 \\
\hline Ability to realize declared programs & 31.0 & 29.3 \\
\hline Education & 9.1 & 10.6 \\
\hline Vitality/health & 5.7 & 5.4 \\
\hline Youth & 2.6 & 2.2 \\
\hline Good managerial skills & 25.4 & 29.7 \\
\hline Respect to laws and justice & 25.0 & 28.4 \\
\hline Commitment to decisive actions & 15.9 & 15.0 \\
\hline Other & 2.0 & 1.5 \\
\hline Don’t know/Difficult to say & 1.1 & 0.7 \\
\hline Refusal to answer & 0.4 & 0.3 \\
\hline
\end{tabular}


As the data show (see Diagram 4), "honesty" was the most desirable quality in a Ukrainian politician. The general political culture of oligarchic influences and wide-spread accusations of both political and administrative corruption provides a background to the large number of voters who emphasized this feature. To be blessed with leaders that play by the rules was a desire uniting many of the Ukrainian voters. In the second round of the presidential elections, Tymoshenko's supporters placed democratic commitment and national orientation higher than Ianukovych's voters did, whereas those who supported Ianukovych valued honesty, experience, and good managerial skills higher (Table 7). However, voters of both candidates clearly valued executive qualities highest: strong hand, experience, managerial skills, and ability to realize declared programs.

Table 7. What traits should effective Ukrainian political leaders have? (\% by political choice)

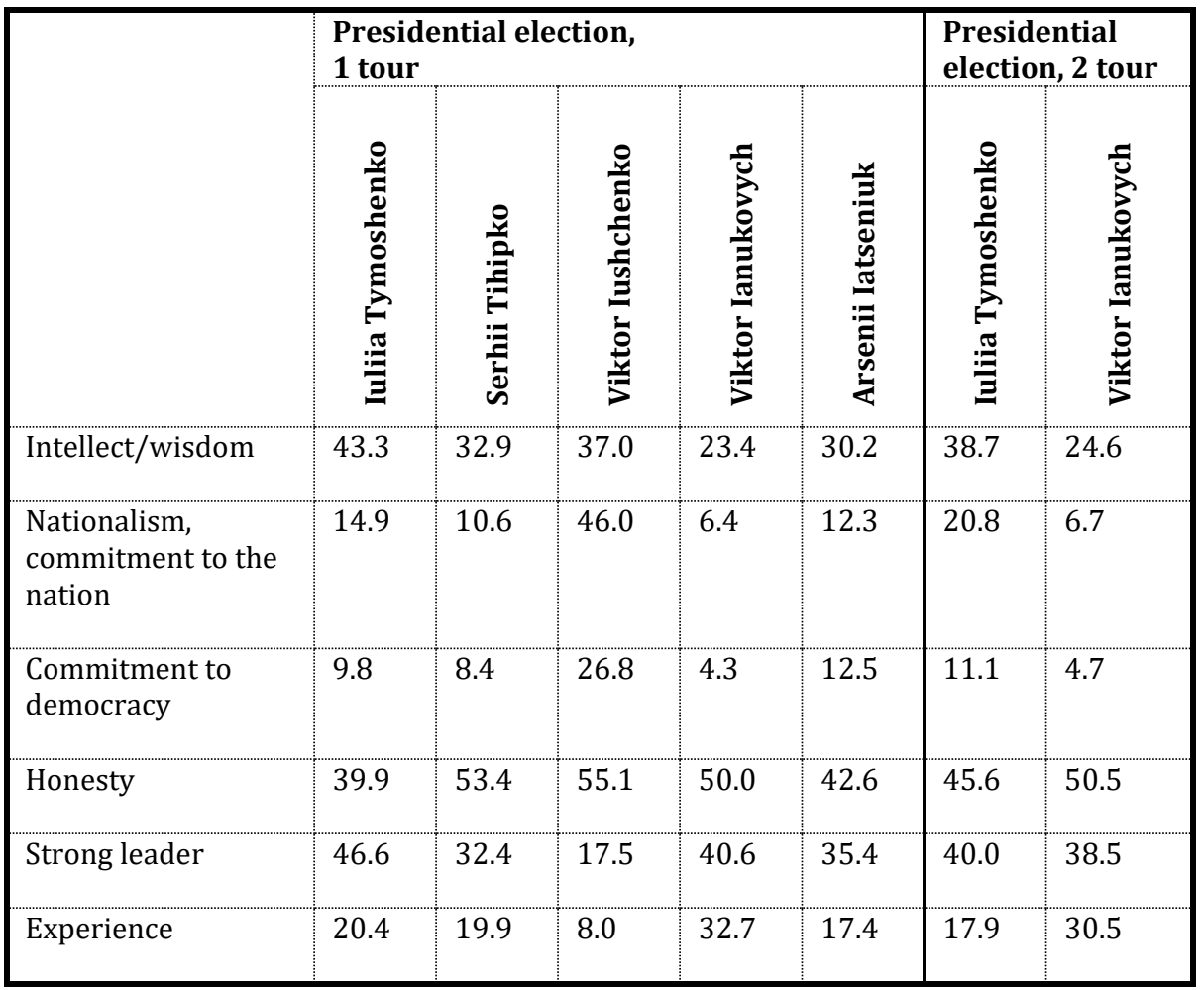


Table 7 continues.

\begin{tabular}{|c|c|c|c|c|c|c|c|}
\hline & \multicolumn{5}{|c|}{$\begin{array}{l}\text { Presidential election, } \\
1 \text { tour }\end{array}$} & \multicolumn{2}{|c|}{$\begin{array}{l}\text { Presidential } \\
\text { election, } 2 \text { tour }\end{array}$} \\
\hline & 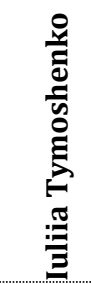 & 胥 & 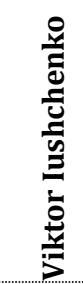 & 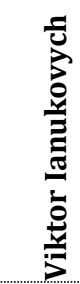 & 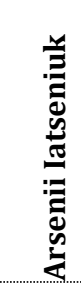 & 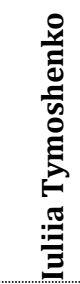 & 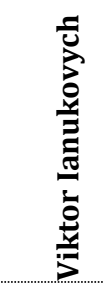 \\
\hline $\begin{array}{l}\text { Ability to realize } \\
\text { declared programs }\end{array}$ & 31.6 & 26.5 & 17.3 & 33.4 & 24.1 & 29.3 & 34.0 \\
\hline Education & 9.5 & 11.1 & 12.2 & 6.3 & 29.5 & 9.8 & 7.4 \\
\hline Vitality/health & 7.7 & 7.4 & 1.9 & 4.8 & 11.8 & 6.5 & 4.6 \\
\hline Youth & 1.5 & 5.7 & 0.0 & 0.5 & 8.9 & 2.1 & 1.2 \\
\hline $\begin{array}{l}\text { Good managerial } \\
\text { skills }\end{array}$ & 26.5 & 35.4 & 13.4 & 34.8 & 23.0 & 24.2 & 32.1 \\
\hline $\begin{array}{l}\text { Respect to laws and } \\
\text { justice }\end{array}$ & 21.0 & 25.9 & 20.1 & 28.2 & 20.1 & 24.2 & 28.8 \\
\hline $\begin{array}{l}\text { Commitment to } \\
\text { decisive actions }\end{array}$ & 14.0 & 17.7 & 11.5 & 17.0 & 14.7 & 13.1 & 17.6 \\
\hline Other & 1.2 & 0.5 & 6.1 & 0.9 & 1.4 & 2.1 & 1.2 \\
\hline $\begin{array}{l}\text { Don't } \\
\text { know/Difficult to } \\
\text { say }\end{array}$ & 1.0 & 0.0 & 2.3 & 0.5 & 0.0 & 0.9 & 0.5 \\
\hline Refusal to answer & 0.0 & 0.0 & 0.0 & 0.4 & 0.0 & 0.0 & 0.3 \\
\hline
\end{tabular}

Both Tymoshenko's and Ianukovych's voters rated highly the strong leadership category - the second most important quality of a political leader. A desire for a "strong leader" has been demonstrated in most postCommunist democracies. The longing for a charismatic leader has often been analyzed as a sign of democratic immaturity, symbolizing disillusion with democratic practices and possibly unrealistic expectations. However, in the 
Ukrainian context, the years of political stale-mate and infighting after the Orange Revolution is a plausible explanation for such desires. The period following the Orange Revolution was characterized by permanent political instability, which negatively affected the national economy and minimized the country's resistance to the global economic crisis of 2008. Opinion polls bear witness to a perception of risk of political and economic instability (13 percent of respondents in February 2005 and 76 percent of respondents in October 2008 believed that Ukraine was heading toward growing instability) (Diagram 5).12

\section{Diagram 5}

"Do you think Ukraine is on the right track toward stability and prosperity in the future, or do you think Ukraine is on a path toward instability and chaos?" (n=1502)

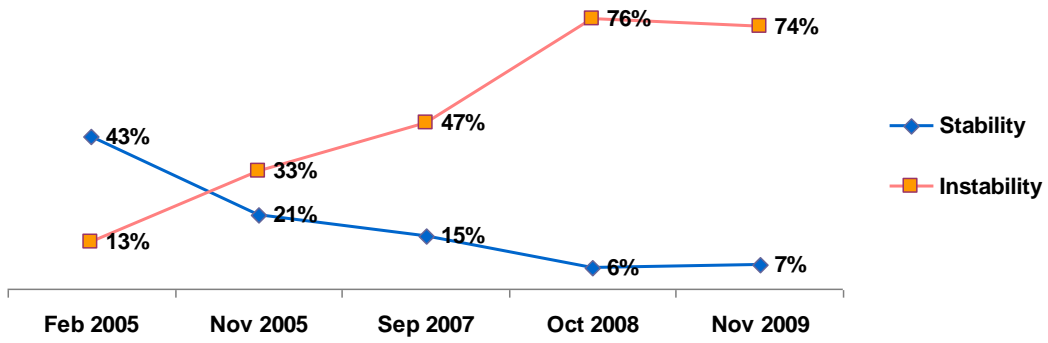

During these turbulent years, the number of those who expected stability to be re-established decreased from 43 percent to 6 . As a reaction to the political and economic turmoil in Ukraine during Iushchenko's presidency we could thus observe a significant demand for strong leadership. In an April 2009 survey conducted by the R\&B Group (Diagram 6), ${ }^{13}$ more than 80 percent of Ukrainians agreed in principle that the country needed a strong-willed president.

12 Based on an IFES (International Foundation for Electoral Systems) monitoring survey ("Public Opinion").

13 Survey of R\&B Group, April 2009, an all Ukrainian sample of 2000 respondents ("Vseukrainskoe issledovanie"). 


\section{Diagram 6}

\section{Do you agree that Ukraine needs a "strong arm" (strong leader) nowadays? \\ (\% from all respondents, $n=2000$ )}

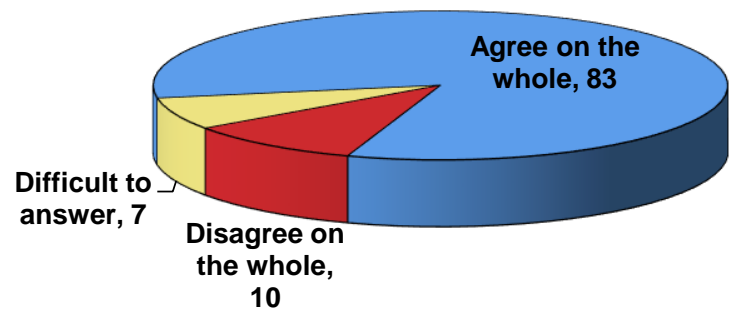

The "strong leader" is characterized by a forceful leadership-even bordering on authoritarianism-and Ukrainians expect decisive actions and an ability to introduce political and economic order in the country from such a leader, even at the expense of limiting democratic rights and freedoms. The procedural (constitutional) leader, on the other hand, is considered to be constrained rather than "strong." Such leader must cope with the situation in the state but the emphasis is on respect for the law.

Table 8. What traits should an effective Ukrainian political leader have?

\begin{tabular}{|lll|}
\hline & Honesty \% & Strong leader \% \\
Intellect/wisdom & 31 & 31 \\
$\begin{array}{l}\text { Nationalism, commitment to the } \\
\text { nation }\end{array}$ & 13 & 11 \\
Commitment to democracy & 6 & 8 \\
Experience & 24 & 25 \\
Ability to realize declared programs & 29 & 30 \\
Education & 10 & 6 \\
Vitality/health & 2 & 6 \\
Youth & 2 & 2 \\
\hline
\end{tabular}




\section{Table 8 continues.}

\begin{tabular}{|lll|}
\hline & Honesty \% & $\begin{array}{l}\text { Strong leader \% } \\
\text { Good managerial skills }\end{array}$ \\
Respect to laws and justice & 31 & 21 \\
Commitment to decisive actions & 10 & 19 \\
\hline
\end{tabular}

In Table 8, respondents who chose "honesty" rather than "strong leader" preferred such qualities as education (10 percent vs. 6 percent) and respect for law and justice ( 30 percent vs. 21 percent) in a leader. Respondents who voted for a "strong leader" rather than for a leader with "honesty" chose vitality/health ( 6 percent vs. 2 percent), good managerial skills (33 percent vs. 21 percent), and commitment to decisive actions (19 percent vs. 10 percent). Specifically, respondents who preferred a strong leader could be said to value personal features and general competence highly, while respondents who desired honesty more than strength tended to value a political culture marked by virtuous behaviour among the leaders. Such respondent behaviour reflected an oscillation in Ukraine between personal and procedural rule, which in itself reflected the influence of different historical traditions: the western, more rule-bound with roots in the AustroHungarian Empire, and the Russian and Slavic autocratic and strong handed leadership.

The low emphasis respondents gave to commitment to democracy as a leadership quality was remarkable. It could be expected that such a commitment would be more valued since only a quarter of the respondents (24 percent) were certain that Ukraine really was a democracy, and almost half of the respondents (49 percent) had an opposite opinion (see Diagram 7). ${ }^{14}$ The low importance that respondents assigned to democratic commitment in a political leader could be an indicator of a lack of democratic tradition. However, economic survival and thus strong reform policies are prioritized over democratic rule in times of crisis and instability.

\footnotetext{
14 Based on an IFES monitoring survey ("Public Opinion").
} 
Diagram 7

\section{“Is Ukraine a democracy?” (n=1502)}

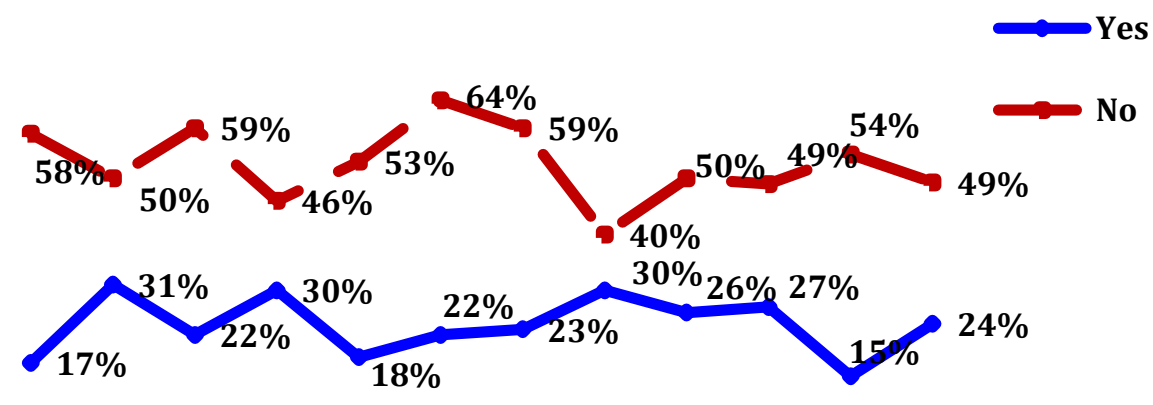

$\begin{array}{cccccccccccc}\text { Jun } & \text { Jan } & \text { Dec } & \text { Sep } & \text { Sep } & \text { Sep } & \text { Oct } & \text { Feb } & \text { Nov } & \text { Sep } & \text { Oct } & \text { Nov } \\ 99 & 00 & 00 & 01 & 02 & 03 & 04 & 05 & 05 & 07 & 08 & 09\end{array}$

WHY DID VIKTOR IANUKOVYCH WIN?

In the politically instable climate that plagued Ukraine after the Orange Revolution, the country's fragile democracy fared ill. On top of that the economic crisis had thrown Ukraine into deep recession. On the eve of the 2010 presidential elections, Ukrainians therefore did not highly value democratic commitment. Looking back on dismal experiences that had led to dead-locks, they were ready to endure more "strong" leadership in exchange for a longed for, improved economic situation. Ianukovych, not renowned for a democratic outlook and backed by the Party of Regions with strong networks and resources, provided hope that jobs and welfare would be priorities, instead of fluffy talk about freedom and democratic values. The Orange alliance had carried the confidence of the Euromaidan protesters and numerous others and had recklessly misused it. Ianukovych won the presidential elections in 2010 because the Ukrainian voters at least partly made informed choices based on their previous experience and given their expectations, although the gap between Ianukovych and the leading Orange candidate Tymoshenko was not large, only 3.5 percent. Their expectations pushed voters to elect a candidate who appeared to be managerial, nonconsensual, and who had roots in a region where the economy was still functioning. These elections show the importance of handling a popular mandate in a fragile democratic environment, such as Ukraine was at the time, with skill and care, in order not to pave way for a tempting reauthoritarianism in the shape of a "strong" leader. Ukrainians elected a 
president who used means to secure the continuous power of his party and reduce the power of parliament, and who took corruption to astronomic levels. Voter expectations were again badly crushed. But the Orange experience of being able to make a difference through popular protest inspired what came to be the Revolution of Dignity and the ultimate ousting of the elected president. In contrast to the Orange Revolution, which has been termed a cultural-ethnic uprising, democratic commitment formed part of the motivation for the 2014 popular mobilization.

\section{CONCLUDING REMARKS}

The 2010 presidential elections are history. In 2013, a "Revolution of Dignity," also known as Euromaidan, culminated in the ousting of President Ianukovych. On May 25, 2014, Petro Poroshenko was elected president by an absolute majority -54.7 percent of the votes-and with a more even support spread over Ukraine than any previous presidential candidate. Tymoshenko finished second, however, with just 12.8 percent. In 2014, by signing the Ukraine-European Union Association Agreement, Ukraine moved in a direction that is constantly challenged by Russia.

There was hope that the 2014 elections would put an end to the "old" generation of Ukrainian political leaders, paving the way for a presidency that catered more to the entire country. However, as of 2017, there has not been the hoped-for break with the past, many from the old generation still populate Ukrainian politics, and high levels of corruption, economic problems, oligarchic control of the media, and a weak and politicized judicial system continue to haunt the country (cf. D’Anieri, "Establishing Ukraine's Fourth Republic"). The party system is still fragile (Fedorenko et al.). However, the importance of civil society has grown after the Revolution of Dignity, indicating a shift toward more grassroots-based engagement (Stewart and Dollbaum). As Brudny and Finkel discuss, Ukraine possesses stronger undertows of democratic concern than neighbouring Russia. Although the 2010 elections brought a potentially criminal regime to power in an orderly democratic way, Ianukovych did not win because Ukrainian voters were fooled or because they specifically liked him. Our analysis shows that he won as a result of the political incapacity that voters perceived in the Orange leaders, worries that were severely aggravated during the economic crisis. He won because Ukrainian voters partly had preferences similar to citizens in many older Western democracies. In a situation of economic recession and hardship, voters prioritized-regardless of region-the fight against unemployment and the implementation of constructive job-policies. Clearly it was these issues - not whether the country should orient itself toward the EU or Russia, not whether Russian should be an official language, 
and not whether there should be a commitment to democracy-that were the major topics when Ukrainians voted for a future president in early 2010. The issues of welfare policies, of pensions, and of increasing wages could be added to the list of voter concerns in 2010. Data and surveys discussed above show that the Ukrainian pattern described here is common to that of populations in the Western world, where voters in general find foreign policy issues or geopolitical relations to be of marginal importance in elections, and economic issues rate highly among voters. The issue of corruption among the Ukrainian voters is a context-specific exception related to the wide-spread tradition of bribes and illicit behaviour involving state officials, practices that continue today.

However, Ianukovych won also because Ukrainians did not prefer a democratic president in the situation at hand; in an economic crisis they were willing to risk electing a "strong-handed" leader. That tells us just how dangerous the combination of economic crisis and political stalemate can be. If Ianukovych had continued to rule, Ukrainian society and the Ukrainian state would have been destroyed for a long time to come.

Works Cited

Applebaum, Anne. Red Famine: Stalin's War on Ukraine. Allen Lane/Penguin Books, 2017.

Bilousov, Serhii. Ob"iektyvna osnova i sub"iektyvni faktory elektoral'noho vyboru naselennia $v$ umovakh suspil'stva, shcho transformuiet'sia (na materialakh Pivdenno-Skhidnoho rehionu Ukrainy). Instytut derzhavy i prava NAN Ukrainy, 2002.

Birch, Sarah. Electoral Systems and Political Transformation in Post-Communist Europe. Palgrave/Macmillan, 2003.

Bloom, Stephen, and Stephen Shulman. "Interest versus Identity: Economic Voting in Ukrainian Presidential Elections." Post-Soviet Affairs, vol. 27, no. 4, 2011, pp. 41028.

Brudny, Yitzhak M., and Evgeny Finkel. "Why Ukraine Is Not Russia: Hegemonic National Identity and Democracy in Russia and Ukraine." East European Politics and Societies, vol. 25, no. 4, 2011, pp. 813-33.

Colton, Timothy J. "An Aligning Election and the Ukrainian Political Community." East European Politics and Societies, vol. 25, no. 1, 2011, pp. 4-27.

Dalton, Russell. Citizen Politics: Public Opinion and Political Parties in Advanced Industrial Democracies. CQ Press, 2006.

D'Anieri, Paul. "Establishing Ukraine's Fourth Republic: Reform after Revolution." Beyond the Euromaidan: Comparative Perspectives on Advancing Reform in Ukraine, edited by Henry E. Hale and Robert W. Orttung, Stanford UP, 2016, pp. 3-20. 
---. "The Last Hurrah: The 2004 Ukrainian Presidential Elections and the Limits of Machine Politics." Communist and Post-Communist Studies, vol. 38, no. 2, 2005, pp. 231-49.

---. Understanding Ukrainian Politics: Power, Politics, and Institutional Design. M.E. Sharpe, 2007.

Denisova-Schmidt, Elena, and Martin Huber. "Regional Differences in Perceived Corruption among Ukrainian Firms." Eurasian Geography and Economics, vol. 55, no. 1, 2014, pp. 10-36.

"Dumky ta pohliady zhyteliv Pivdenno-skhidnykh oblastei Ukrainy: Kviten' 2014." KIIS, $\quad$ http://www.kiis.com.ua/?lang=ukr\&cat=reports\&id=302\&page=1. Accessed 10 June 2018.

Fedorenko, Kostyantyn, et al. "The Ukrainian Party System before and after the 20132014 Euromaidan." Europe-Asia Studies, vol. 68, no. 4, 2016, pp. 609-30.

Hale, Henry. Patronal Politics: Eurasian Regime Dynamics in Comparative Perspective. Cambridge UP, 2015.

Huhnin, Eduard. Topolohichni kharakterystyky elektoral'noho polia Ukrainy. Humanitarnyi universytet "Zaporizh'kyi instytut derzhavnoho i munitsipal'noho prava," 2007.

Iashchenko, Anna. "Chy prava Tymoshenko, iaka kazhe, shcho kryza nas obmynaie?" Informatsiine ahenstvo UNIAN, 16 Oct. 2008, https://www.unian.ua/politics/154023-chi-prava-timoshenko-yaka-kaje-schokriza-nas-obminae.html. Accessed 10 June 2018.

Idrisov, Bakhtiior. Elektoral'na kul'tura naselennia Ukrainy v umovakh transformatsii suspil'stva. Instytut sotsiolohii NANU, 2006.

Korostelina, Karina V. "Ukraine Twenty Years after Independence: Concept Models of the Society." Communist and Post-Communist Studies, vol. 46, no. 1, 2013, pp. 53-64.

Kovalov, Maksym. "Electoral Manipulations and Fraud in Parliamentary Elections: The Case of Ukraine." East European Politics and Societies, vol. 28, no. 4, 2014, pp. 781-807.

Kubicek, Paul. "Regional Polarisation in Ukraine: Public Opinion, Voting and Legislative Behaviour.” Europe-Asia Studies, vol. 52, no. 2, 2000, pp. 273-94.

Kushakova, Maryna. "Analiz zaluchennia manipuliatyvnykh politychnykh tekhnolohii prezydents'koi vyborchoi kampanii 2010 roku." Naukovi pratsi: Politolohiia, vol. 236, no. 224, 2014, pp. 46-50. http://nbuv.gov.ua/UIRN/Npchdupol 2014236224 11. Accessed 19 June 2018.

Kuzio, Taras. "Rise and Fall of the Party of Regions Political Machine." Problems of Post-Communism, vol. 62, no. 3, 2015, pp. 174-86.

---. "Ukrainian Kleptocrats and America's Real-Life House of Cards: Corruption, Lobbyism and the Rule of Law." Communist and Post-Communist Studies, vol. 50, no. 1, 2017, pp. 29-40.

Mykhailych, Oleksandr. Etnorehional'ni ta linhvistychni chynnyky elektoral'nykh oriientatsii vybortsiv suchasnoi Ukrainy. Natsional'nyi universytet im. Tarasa Shevchenka, 2007. 
O'Brien, Thomas. "Problems of Political Transition in Ukraine: Leadership Failure and Democratic Consolidation." Contemporary Politics, vol. 16, no. 4, 2010, pp. 355-67.

Onuch, Olga. "Who Were the Protesters?" Journal of Democracy, vol. 25, no. 3, 2014, pp. 44-51.

Osipian, Ararat L., and Alexandr L. Osipian. "Regional Diversity and Divided Memories in Ukraine: Contested Past as Electoral Resource, 2004-2010." East European Politics and Societies, vol. 26, no. 3, 2012, pp. 616-42.

"Public Opinion in Ukraine 2009: Findings from an IFES Survey." IFES.org, http://www.ifes.org/sites/default/files/mediapackchartsfromifesukraine2009s urvey 2.pdf. Accessed 10 June 2018.

Puglisi, Rosaria. "The Rise of the Ukrainian Oligarchs." Democratization, vol. 10, no. 3, 2003, pp. 99-123.

"Reitingi prezidenta i pravitel'stva: Vopreki pozharam i smogu." VCIOM, 2 Sept. 2010, https://wciom.ru/index.php?id=236\&uid=1879. Accessed 10 June 2018.

Reznik, Oleksandr. "From the Orange Revolution to the Revolution of Dignity: Dynamics of the Protest Actions in Ukraine." East European Politics and Societies, vol. 30, no. 4, 2016, pp. 750-65.

Ryabov, Andrei. "Post-Soviet Gravitation: On the Results of the Presidential Elections in Ukraine." Russian Politics \& Law, vol. 49, no. 5, 2011, pp. 34-42.

Simon, Gerhard. "Change at the Ballot Box The Presidential and Parliamentarian Elections." OSTEUROPA, vol. 64, no. 9-10, 2014, pp. 155-67.

Slomczynski, Kazimierz M., et al. "Fluid Party Systems, Electoral Rules and Accountability of Legislators in Emerging Democracies: The Case of Ukraine." Party Politics, vol. 14 no. 1, 2008, pp. 91-112.

Snyder, Timothy. Bloodlands: Europe between Hitler and Stalin. Basic Books, 2010.

Stewart, Susan, and Jan Matti Dollbaum. "Civil Society Development in Russia and Ukraine: Diverging Paths." Communist and Post-Communist Studies, vol. 50, no. 3, 2017, pp. 207-20.

Szostek, Joanna. "Virtual Issue: Revolution in Progress? Continuity and Change in Ukrainian Politics." East European Politics and Societies and Cultures, vol. 31, no. 4, 2017, pp. 909-922, http://journals.sagepub.com/doi/abs/10.1177/0888325417737664. Accessed 10 June 2018.

“Ukraine GDP per Capita: 1987-2018." Trading Economics, https://tradingeconomics.com/ukraine/gdp-per-capita. Accessed 10 June 2018.

Wilson, Andrew. "Ukraine's Orange Revolution, NGOs and the Role of the West." Cambridge Review of International Affairs, vol. 19, no. 1, 2006, pp. 21-32.

---, and Sarah Birch. "Voting Stability, Political Gridlock: Ukraine's 1998 Parliamentary Elections." Europe-Asia Studies, vol. 51, no. 6, 1999, pp. 1039-68.

"Vseukrainskoe issledovanie obshchestvennogo mneniia." Docplayer, uploaded by Marina Burmantova, http://docplayer.ru/27801120-Vseukrainskoeissledovanie-obshchestvennogo-mneniya.html. Accessed 10 June 2018.

Vyshniak, Oleksandr. Elektoral'na sotsiolohiia: Istoriia, teoriia, metody. Instytut sotsiolohii NANU, 2000. 
Yurchuk, Yulija. Reordering of Meaningful Worlds. Memory of the Organization of Ukrainian Nationalists and the Ukrainian Insurgent Army in Post-Soviet Ukraine. Dissertation, Stockholm University, 2014. 